\title{
How to Manage and Plan Terminology: Creating Management TDBs
}

UDC: 005.912:81'25

005.92:004.63

DOI: 10.7595/management.fon.2016.0013

\begin{abstract}
Scientific and technical terminology represents a very topical issue in economically and technologically dependent countries with small languages such as Serbian. The current terminological problems in the Serbian language, especially in specialized areas that are experiencing dynamic development, are: Anglicization of the language for special purposes, underdeveloped and unstable terminology, and lack of adequate and modern terminological and lexical resources. On the one hand, the terminological problems listed above are of concern to subject-field specialists, since inadequate and non-existent terminology significantly affects the representation, transfer and management of specialized knowledge and information. On the other hand, terminology and language planners point to the growing need for immediate and systematic intervention aimed at terminology harmonization, consolidation and standardization. In spite of the awareness, there is no systematic approach to the solving of terminological problems in Serbian. In addition, practical activities regarding the collection and organization of terminology are few and reduced to individual initiatives.

Under the paradigm of language planning (LP)-oriented terminology management (2), this paper is going to address a practical activity of terminology management: the creation of a Serbian management terminology database (TDB) with equivalent terms in English. The paper will discuss the methodology of terminology work, potential obstacles in termbase creation, as well as potential benefits that such a resource would have on all its potential users: management specialists and practitioners, professional translators, and language and terminology planners. A particular focus will be placed on the potential significance that this kind of a database would have for terminology policy and planning in the Serbian language, on the one hand, and knowledge transfer and management, on the other hand.
\end{abstract}

Keywords: terminology database (TDB), terminology management, management terminology, language planning, terminology knowledge base (TKB)

\section{Introduction}

Terminology is the major constituent element of every language for special purposes (LSP) and a prerequisite for professional communication, accurate exchange of specialized information and the transfer and management of knowledge. Subject field information and knowledge cannot be generated, used (e.g., in specialized texts), recorded and processed (e.g., in databases), passed on, transferred, translated or interpreted without the use of the appropriate terminological units, i.e., units of knowledge (Guidelines for terminology policies, 2005).

In recent decades, terminology has become one of the topical issues of scientific research in many disciplines, such as language policy and planning, applied and computational linguistics, standardization, knowledge management and natural language processing. The main reason behind this lies mainly in two parallel processes: globalization and internationalization of professional terminology for easier and more efficient communication, on the one hand, and localization, i.e., translation or adaptation of the terminology used in local, small languages with the aim of preserving linguistic and cultural identity and diversity, on the 
other hand. The English language has undoubtedly become the international lingua franca and the most important terminology provider in almost all scientific and technical areas, and is thus in constant need of new terms to name newly emerging concepts.

Even though terminological issues are encountered throughout the world, it seems that they are most prominent in economically, technologically and politically dependent countries with small languages (Piper, P., 1998) such as Serbian. The current terminological problems in the Serbian language, especially in subject fields that are experiencing dynamic development, are: the Anglicization (or Anglo-globalization) of the language for special purposes, underdeveloped and unstandardized terminology, term variation and synonymy, as well as a lack of adequate and up-to-date terminological resources. The main objective of terminology planning in the Serbian language should be a conscious and systematic development of specialized terminology with the purpose of making specialized discourse functional and enabling adequate professional communication in the language in question.

The terminological problems in Serbian listed above are of most direct concern to subject-field specialists and professional translators, since inadequate and non-existent terminology significantly affects the representation, transfer and localization (i.e., translation) of specialized knowledge. However, this issue is of major importance for language planners as well. Terminology represents a strategic resource: if a specialized language community lacks adequate scientific and technical terminology, it runs the risk of losing the ability to support professional communication in the given field of expertise (Filipović, J., 2002). The specialized language is therefore in urgent need of immediate and systematic intervention by language and terminology planners in order stay functional. In Serbia, however, there is neither a systematic approach to the solving of terminological problems in Serbian nor enough funds allocated for this purpose.

Outside Serbia, the need to form and harmonize terminology in small languages has initiated a series of practical terminological and terminographical activities that are jointly named terminology management as a part of knowledge management (Wright, E.E. \& Budin, G., 1997). An issue of particular importance in terminology management is the application of information technologies in the development of electronic terminological resources, primarily monolingual and multilingual terminology databases and terminological knowledge bases, which have been carried out through individual and national projects and represent a very significant terminological resource and contribute to terminology and language policy and planning.

\subsection{Terminology Management, Planning and Standards}

Terminology management (TM) is a relatively new term coined with the purpose of adequately addressing terminology problems in all languages that can be defined as any deliberate manipulation of terminology information (Wright, E.E. \& Budin, G., 1997). It covers a wide range of prescriptive and descriptive TM activities, ranging from the creation of new concepts and corresponding terms, collection of terminology in terminological resources (dictionaries, lexicons, termbases, etc.), provision of terminological services, to harmonization and standardization of terminology. TM also has a wider significance since it contributes to the development of various other disciplines, such as knowledge transfer and technical translation, knowledge and information management, standardization, language policy and planning, etc. For TM activities in general, the following international standards are relevant: ISO 704:2009 - Terminology work Principles and methods, ISO 860:2007 - Terminology work - Harmonization of concepts and terms, ISO 10871:2000 - Terminology work - Vocabulary - Part 1: Theory and application, ISO 10241-1:2011 - Terminological entries in standards - Part 1: General requirements and examples of presentation.

In this paper, a particular focus will be placed on the creation of terminology databases - termbases (TDBs) and their potential significance for terminology policy and planning, on the one hand, and knowledge transfer and management, on the other hand. More precisely, we will discuss the possibility of creating a termbase for the subject-field of management in Serbian (with equivalents in English), potential benefits of such a TDB for a wide range of users, and a proposed methodology for terminology work in management terminology database creation. Thus presented, the abovementioned terminological activities belong to the paradigm of language planning (LP) oriented terminology management (Antia, E.B., 2000). 


\section{Overview of TDBs}

Comprehensive and accessible terminology resources have become a growing requirement in today's rapidly developing specialized subject fields. One of the most frequent terminology resources available online are terminology databases (termbases). Terminology database (TDB) is an electronically accessible, practical and up-to-date terminological resource, open for constant upgrade and easy to use. It is a database containing structured concept-oriented terminological data, that is, subject-specific concepts and terms that designate them. The main advantage of an electronically accessible termbase over terminological resources found in paper is that it would be more comprehensive, up-to-date, and open for constant upgrade and expansion. For an example of a typical TDB interface, see Figure 1 below.

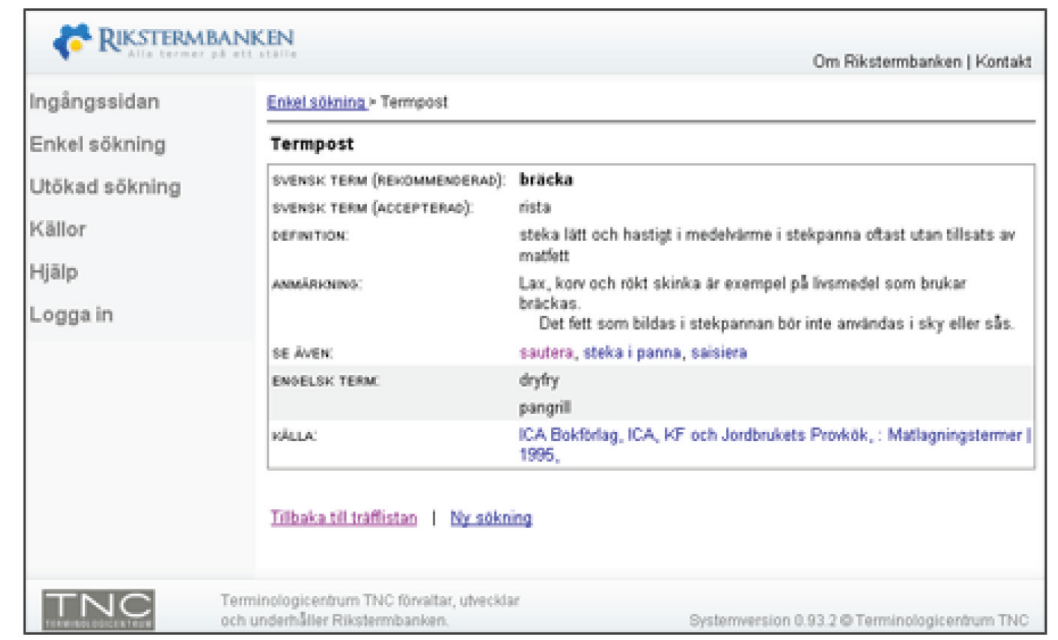

Figure 1: An example of a TDB: Rikstermbanken

Despite a relatively large number of existing TDBs, they seem to vary significantly with regard to their size, accessibility, design, structure and methodological approach, and also to depend on particular needs or preferences. TDBs can be created in different software environments and range in complexity and the number of data categories (categories of terminological information) available for each terminological entry.

TDBs can be (a) monolingual (with or without equivalents in (an)other language(s), bilingual and multilingual, (b) designed for a particular subject field or encompassing several of them, (c) institutional termbases (generally aimed at in-house translators and not publicly accessible) and national databases (created as a TM activity contributing to the national terminology and language policy and planning). Even though the principal users of TDBs are translators, termbases have applications in technical writing and domain learning, as well as information retrieval, machine translation, etc., which makes subject-field specialists and practitioners potential users of TDBs as well.

The main weakness of TDBs is that they provide mainly linguistic information about terms. Nowadays, a growing number of terminology researchers call for an evolution of TDBs into a new, knowledge-based generation of resources called terminology knowledge bases - TKBs (Meyer et. al. (1992). In addition to linguistic information, TKBs also contain conceptual information, regarding not only definitions of terms and context of use, but also graphical representation of concepts in the form of a semantic net (conceptual tree or map) containing hierarchical and non-hierarchical relations between concepts designated by terms. This conceptual approach to terminology work, according to Vargas Sierra (3) can result in more controlled, consistent, logical and systematic terminology resources. Ecolexicon, a TKB for the subject-field of Environment (see Figure 2), for example, was developed at the University of Granada, Spain, as a result of several projects. 


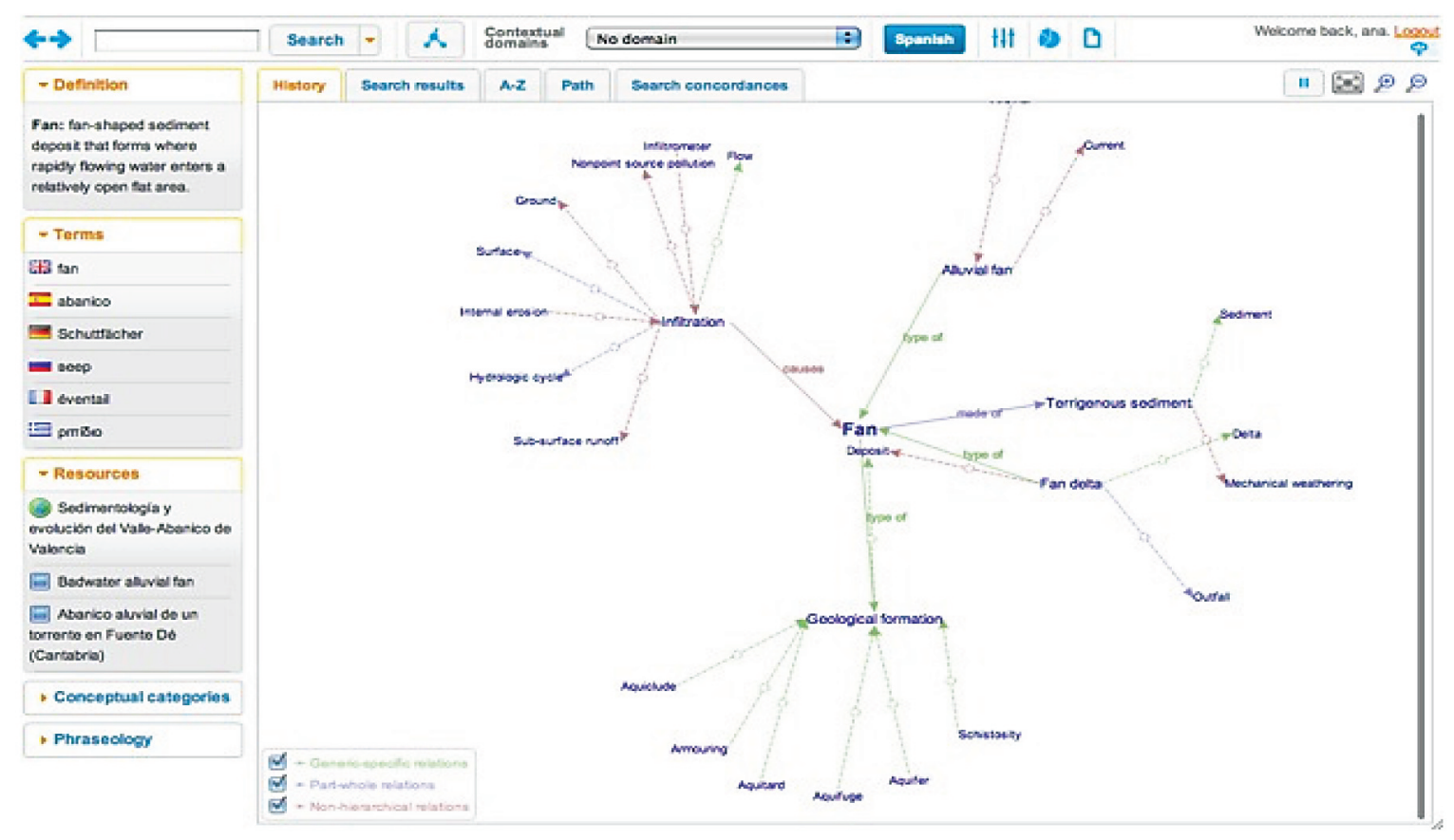

Figure 2: Example of a TKB: Ecolexicon

\subsection{National TDBs}

The creation of national terminology databases seems to be one of the most significant terminological activities in European countries nowadays. National TDBs are in most cases normative and are used as one of the primary tools for the implementation of a national terminology policy and planning. The practical activity of collecting terminological data and consolidating them in a national TDB is therefore of particular importance for smaller and endangered languages. However, the number of comprehensive national termbases is scarce due to limited financial resources and coordination between institutions dealing with terminological activities.

There are two general approaches to the creation of a national termbase: through a national terminological centre or through a series of independent projects focusing on terminology of particular subject-field domains that later become integrated into one multi-domain national termbase. The design, structure, formatting and methodological approaches employed in a national TDB creation differ and depend on the needs of a particular language community.

Termium Plus, one of the largest national termbases in the world that provides access to millions of terms in English, French, Spanish and Portuguese, is operated and maintained by the Translation Bureau under the Government of Canada (). Probably the biggest national TDB in Europe is Rikstermbanken, created by the oldest and the most active terminology centre in Europe - the Swedish National Centre for Terminology TNC (Terminologicentrum). As a result of strong financial support coming from the Swedish government, Rikstermbanken nowadays contains approximately 627,000 term records with equivalents in more than 20 languages (BSK, Catalan, Danish, English, Estonian, Faroese, Finnish, French, German, Greek, Greenlandic, Icelandic, Japanese, Latin, Northern Sami, Norwegian (bokmål), Norwegian (nynorsk), Polish, Russian, Spanish, Swedish, and Turkish). The most significant terminological database in our region is the Croatian national terminology database Struna (struna.ihjj.hr). Struna has been implemented through a series of coordinated projects under the guidance of the Institute of Croatian Language and Linguistics. Struna is now a publicly accessible termbase, prescriptive in approach, aimed at Croatian LSP terminology standardization (Brač, I., Lončar, M.: 2012), and largely organized according to ISO/TC 37 terminological standards. It currently has around 42,000 terminological entries that belong to 20 subject-field domains. 


\subsection{Institutional and Subject Field - specific TDBs}

Practical terminology management activities can be performed in a variety of institutions, public agencies, universities and private companies that can establish their own terminology and internal terminology databases. These termbases are mostly created to facilitate the work of in-house translators and technical writers and to ensure the consistency in the use of terminology.

Among the largest TDBs created to fulfill the needs of particular institutions are the ones initiated by the United Nations (UNterm database, consisting of 70,000 term entries in six languages), the NATO (; encompassing 35 glossaries, databases, terminology lists and online dictionaries), the World Trade Organization (), the Unesco (), the International Monetary Fund (), the Terminology Centre within the University of Ghent (), the Norwegian Association of Higher Education Institutions ( database termbase.uhr.no), the International Telecommunications Union - a termbase for the subject field of telecommunications (), the International Electrotechnical Commission - for the domain of electronics and electrical engineering (http://www.electropedia.org/), etc.

\subsubsection{Intra-institutional TDBs of the EU}

Having that consistent, harmonized and easily accessible terminology is extremely important for ensuring true multilingualism in the European Union, it is not surprising that the most extensive institutional terminology database is IATE (Inter-Active Terminology for Europe, ), the European Union' s termbase used in the EU institutions and agencies since the summer 2004 for the collection, dissemination and shared management of EU-specific terminology. It includes more than 9 million terms belonging to more than 20 subject-field domains in the 25 official EU languages.

Several multilingual TDBs have been created by translators in the languages of the Western Balkans for the purpose of adequate translation of EU accession documents:

Evronim (http://prevodjenje.seio.gov.rs/evronim/index.php?jezik=engl) in Serbia,

BlHterm (http://bihterm.anyterm.info/index.php?jezik=engl) in Bosnia,

Monterm (http://www.eiprevod.gov.me/index.php?jezik=engl) in Montenegro,

Evroterm (http://www.evroterm.gov.si/index.php?jezik=angl) in Slovenia.

\subsection{TDB Creation Activities in Serbia}

Whereas a large number of terminological resources already exist in European countries, the number of electronically accessible terminological resources in Serbian, and termbases in particular, is extremely scarce, and the terminological coverage is minimal. In addition, none of the multilingual TDBs listed above offers term equivalents in Serbian (apart from Evronim).

In Serbian, only a few projects have been initiated with the purpose of creating electronically accessible subject field - specific terminology resources, i.e., thesauri and termbases. Namely, several years ago, the Faculty of Mining and Geology (FMG), University of Belgrade, initiated the development of several terminological resources with the purpose of simplifying translation in the subject-field in question. One of the resources created by the terminology team at FMG is a publicly accessible bilingual terminological dictionary GeolISSTerm (, in form of a thesaurus of geological terms for the Ministry of the Environment, Mining and Spatial Planning (Blagojević, B., 2011).

A dictionary of Library and Information Sciences DLI ONLINE, in Serbian, English and German, was created in 2014 by the Scientific Research Department of the National Library of Serbia. It is available both online (I) and in print.

Terminological resources, mainly TDBs, for several other subject-field domains in Serbia (mining, electrical energy, spatial planning, geology and e-learning) are in the process of preparation (in the initial phases: corpus design and term extraction) according to the Serbian Society for Language Resources and technologies (Stanković, R., 2016). 
It goes without saying that there has been no attempt at consolidating the existing (though scarce) domainspecific databases towards a national terminology infrastructure and a national terminology database in Serbia, despite the recognized need for a more responsible terminology management and planning.

\section{Serbian TDB for Management}

The discipline of management has, throughout its relatively short history, undergone a continuous and dynamic growth and development, thus producing a constant need for terms to mark newly emerging concepts. The users of management terminology in the Serbian language have shown a tendency to randomly resort to foreign management terms. The newly adopted, but only partly adapted terminology is mostly English, given that the largest part of the latest scientific breakthroughs and technical solutions and the corresponding body of literature come from the developed English-speaking world (Anđelković, J., 2013). This has all resulted in a disorderly state of terminology for the subject-field of management, evident terminology variation, lack of systematization, and the problem of outdated terminological resources in the Serbian language ${ }^{1}$ that are adapted to the needs of subject-field practitioners only and of little significance to other users of management terminology.

In our opinion, terminological gaps and other issues concerning Serbian management terminology presented above call for a systematic approach to managing management terminology. A practical terminological activity of particular importance for the TM process would be the creation of a TDB that would consolidate the existing subject field terminology, point to the issues and concerns, and potentially contribute to the Serbian terminology and language policy, planning and standardization.

It is important to note that this paper does not attempt to represent the processing of a TDB from the perspective of language engineering and expert systems. It rather attempts to propose a methodology for extracting terminological (linguistic and conceptual) information from subject-specific texts and presenting it in the form of a term entry template.

\subsection{Management TDB - Proposed Methodology for Terminology Work}

The creation of a comprehensive terminology database for any specialized subject field represents a complex collaborative activity performed by a team of people that have at least one of the three main competencies: subject- field (or conceptual) knowledge (subject- field specialists), linguistic knowledge (linguists and terminologists) and knowledge of the methodology for terminology work (Cabre, M.T., 1998)

\subsubsection{Preparatory Steps for Management TDB Creation}

Before the actual TDB creation, there are several decisions that need to be made in order to direct our terminology work towards achieving best results. The questions that need to be answered are: (1) what the purpose of our TDB is, (2) what end-users the TDB is aimed at, (3) what terminological data categories it should provide for each term entry, (4) how extensive and detailed the TDB should be, and (5) what software environment we should use for corpus and terminology management.

Firstly, the purpose of creating a management TDB is to collect and present the available terminology information and thus document the current terminology situation in the subject field of management in the Serbian language. Such a database would contribute to terminology planning for this field of expertise, and prepare the grounds for the prescriptive terminological activity of standardization. This purpose of a management TDB is in accordance with the Guidelines for terminology policies issued by the International Terminology Organization Infoterm and the UNESCO.

${ }^{1}$ In the past couple of decades there have been no attempts at collecting management terminology in Serbian and presenting it in the form of a glossary, dictionary, lexicon, or a termbase. The last terminographic product regarding the subject-field of management in the Serbian language is, to our knowledge, Leksikon Menadžmenta (author Petar Jovanović, issued in 2003). 
Secondly, our TDB would be aimed at three groups of users: primarily translators, then subject-field specialists and practitioners when faced with a terminological issue, and, potentially, language and terminology planners, as well.

The choice of TDB end-users is directly related to terminological data categories provided for each TDB entry $^{2}$. Namely, the choice of data categories should correspond to the anticipated needs of the potential TDB users. The data categories that can be chosen from drop-down menus on the database interface can be divided according to the level that they belong to:

(a) Concept level: subject field and subfield, definition (and its source), place of the term in the conceptual structure of the field (i.e., subordinate, superordinate, related or coordinate concept), etc.

(b) Term level: term, standardization label, synonyms, antonyms, context, equivalent(s) in English, abbreviation (a source of each data category should be stated);

(c) Language level: grammatical information (part of speech).

Data categories mandatory for all the terminological entries in our management terminology database should be: preferred term, grammatical information, definition, and equivalent in English. In case a term has synonyms, each one can be marked with one of the following labels: preferred, admitted, deprecated, obsolete, colloquial, proposed.

The number of terminological entries that a Serbian management TDB may have is difficult to predict, having in mind the complexity and the multidisciplinarity of the subject field in question. In order to delimitate the scope of terminology work, modern, cognitive-based terminology theories suggest sketching a conceptual structure of the subject-field in question (Cabre, M.T.: 1998, Meyer, I., et al., 1992). A preliminary conceptual structure for the subject field of management would identify the key concepts and their interrelations, and thus help us in identification of subfields and hierarchical (generic and partitive) and non-hierarchical (associative) relations between terms. It would also facilitate the choice of an extraction corpus (see 3.1.2.).

Based on preliminary conceptual structure, and due to the complexity of work itself, we have decided that the initial phase of management TDB should be limited to around 200 most general and most frequent terms, i.e., terminological entries belonging to the field of management, divided in several proposed subfields, for example: management process, management theory, management team, and management discipline.

Lastly, for a successful handling of terminological data, an important step is the choice of appropriate terminology application software and terminology management systems (TMSs), i.e., tools designed to record, store, process and output terminological data. Since the focus of this paper is on linguistic and conceptual information regarding management terminology in the Serbian language rather than on technological means of handling this information, this issue will not be considered in greater detail. It is, however, important to note that the software environment chosen for a TDB $^{3}$ should allow easy updating and improvement, have a user-friendly interface that provides end-users with ease and accuracy of processing terminology entries. The database should also be compatible with ISO standards regarding terminology work, especially with TermBase eXchange (TBX), ISO 30042:2008 and TMF (Terminological Markup Framework), ISO 16642:2003. Ideally, the terminology tool used in the creation of a TDB should integrate corpus and terminology management and enable corpus search, term extraction, database creation and maintenance, such as, for example, Spanish Terminus 2.0.

\subsubsection{Corpus Design and Extraction of Terms and Term-related Information}

A corpus can be defined as "a collection of texts assumed to be representative of a (.....) subset of language, to be used for linguistic analysis"(10). The quality of the terminographic activity depends heavily on the selection of the extraction corpus. Therefore, it is necessary for the extraction corpus to be designed according to a set of criteria (Cabre, M. T., 1998) with the purpose of providing knowledge-rich contexts for

\footnotetext{
${ }^{2}$ A complete list of data categories with explanations can be found in ISO 12620: 1999. For the purpose of our work, only data categories listed above have been chosen.

${ }^{3}$ The Croatian national TDB Struna, for example, was made in SQL environment.
} 
best results of terminology extraction. An adequately chosen corpus can provide us with both linguistic information on concept and term level (relations among concepts, definitions, synonyms, contexts, etc.), and with extra-linguistic, i.e., encyclopedic knowledge.

For the purpose of extracting terms and term-related information, a specialized parallel (Serbian- English) corpus composed of texts belonging to the knowledge domain of management can be made. As to its size, we believe that it needs to have at least 100,000 words to satisfy the corpus adequacy and representativeness principle. A monitor corpus consisting of international standards and their translations into Serbian (series ISO 9000) should be collected as well with the purpose of verifying the standardization status of the proposed terms.

\subsubsection{Extraction of Terms and Term-related Information}

Once a specialized corpus for the knowledge domain of management was made, term candidates can be extracted manually or automatically, by using a term extraction software such as TermoStat and AUTOTERM. Statistical methods in term extraction should be combined with observing concordances, i.e., collocational and syntactic patterns of terms since the frequency of many terms, especially multi-word ones, is low (Pearson, J., 1998). Concordances of terms (detected through the use of a concordancer such as, for example AntConc) are useful for discovering term variants, especially synonyms, and filtering term candidates to eliminate the ones belonging to general language or other domains, and thus shortlisting term candidates. In addition, concordances can point to hierarchical and non-hierarchical conceptual relations between detected terms.

In addition to extraction corpus, additional source of information on terms can be a set of reference documents, i.e., the existing lexicographical and terminographical resources.

Depending on the corpus selection, the term extraction process may bring about the following list of frequent management terms in Serbian with their equivalents in English (Table 1):

Table 1: Potential list of corpus-extracted terms

\begin{tabular}{|l|l|}
\hline Serbian term(s) & English equivalent(s) \\
\hline Rukovođenje Menadžment Upravljanje & Management \\
\hline Kontrola & Inspection Control \\
\hline Upravljanje & Control \\
\hline Najviše rukovodstvo Top menadžment & Top Management \\
\hline Menadžer srednjeg nivoa Srednji menadžer & Middle Manager \\
\hline Strateški menadžment Strategijski menadžment & Strategic Management \\
\hline Menadžment rizikom Upravljanje rizikom Menadžment rizika & Risk Management \\
\hline Menadžment ljudskih resursa Upravljanje ljudskim resursima & Human Resource Management \\
\hline Menadžment organizacionih promena & Change Management \\
\hline Menadžment znanja Upravljanje znanjem Menadžment znanjem & Knowledge Management \\
\hline Menadžment na licu mesta & Management by Walking Around \\
\hline Menadžment finansija Finansijski menadžment Upravljanje finansijama & Financial Management \\
\hline Marketing menadžment & Marketing Management \\
\hline Interesna strana Zainteresovana strana Stejkholder & Stakeholder \\
\hline Kost benefit analiza Cost-benefit analiza Analiza troškovi - korist & Cost- Benefit Analysis \\
\hline
\end{tabular}




\subsubsection{Terminological Records}

During and after the extraction of management terms from the chosen corpus, terminological information should be recorded in the form of terminological records (Cabre, M.T., 1998). A terminological record for each term entry should contain all the relevant information classified into data categories listed in 3.1.1.2 above.

Table 2: Terminological record template for management TDB

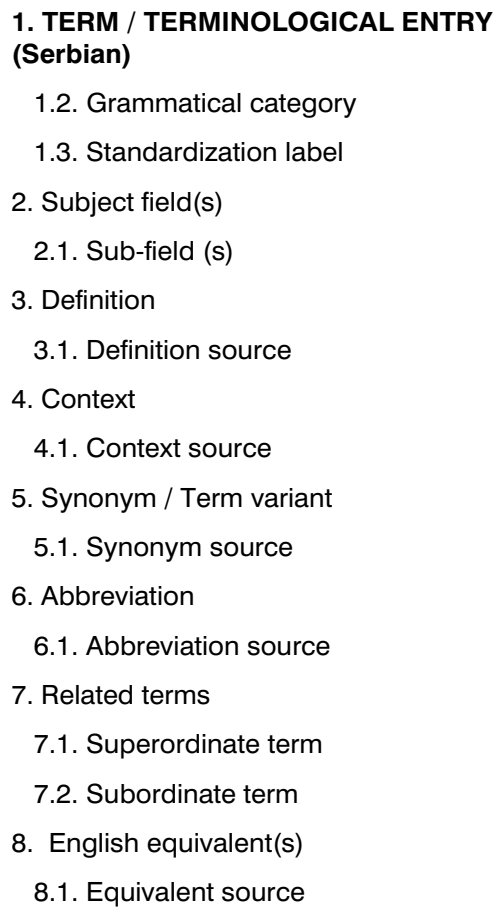

We have chosen to illustrate the use of the template (Table 1 above) in preparation of a TDB with the following example (Table 2):

Table 3: Term entry Menadžment

\begin{tabular}{|l|l|}
\hline TERM & Menadžment noun, standardized \\
\hline Subject field & menadžment*, organizacija* $^{\star}$ \\
\hline Subfield & $-^{\star}$, menadžment* \\
\hline Definition & $\begin{array}{l}\text { Koordinirane aktivnosti za utvrđivanje pravca i upravljanje organizacijom } \\
\text { Source: ISO 9000:2005 (Quality management systems -- Fundamentals and } \\
\text { vocabulary) }\end{array}$ \\
\hline Context & $\begin{array}{l}\text { Nastanak i razvoj menadžmenta kao naučne discipline vezuje se za imena } \\
\text { Frederika Tejlora I Henrija Fajola.. } \\
\text { Source: Jovanović, P. (2009). Savremeni menadžment. Viša škola za projektni } \\
\text { menadžment: Beograd }\end{array}$ \\
\hline Synonym & $\begin{array}{l}\text { Upravljanje preferred, proposed, admitted } \\
\text { Rukovođenje* obsolete }\end{array}$ \\
\hline English equivalent & Management \\
\hline
\end{tabular}

Table 2 draws attention to some management terminology issues and concerns that are going to be addressed in the following section. The problematic data categories are marked with an asterix $\left(^{*}\right)$. 


\subsection{Management TDB - potential Problems and Obstacles}

During the process of terminology database creation, several possible issues may arise. We have decided to divide them into (a) general - the ones that can be encountered during termbase creation in any subject field in the Serbian language, and (b) subject - specific - the ones typical for the subject -field of management.

\subsubsection{General Termbase Creation Issues}

a) Extraction corpus. The Serbian language does not have publicly available corpora for specialized purposes. In other words, Serbian terminology researchers need to create corpora to serve their own research needs.

b) Problems with term extraction. Due to complicated morphology, the Serbian language texts cannot be easily searched for terminology and term-related information, but rather need to be lemmatized and pre-processed before terms are extracted and entered into a database.

c) There may be possible disagreements between subject-field specialists and language experts regarding the preferred usage of certain terms.

d) If a terminologist does not have a high degree of familiarity with the subject field under consideration, problems may be encountered in any stage of TDB creation.

\subsubsection{Subject - specific Termbase Creation Issues}

a) Delimitation of the subject field: The subject field of management cannot be clearly delimitated from several other disciplines, including organization, since they often share common concepts and terminologies. In other words, terms entered into a management termbase may be found in TDBs for other subject fields. In addition, another problem may arise from the fact that the term menadžment can be observed as a subordinate term to organizacija, on the one hand, but also as its superordinate term, since organization is one of the functions of management (Jakić, G., 2014).

b) Polysemy and synonymy of terms: The key term of the subject field of management - the term menadžment itself - is polysemous, since it can refer to either a process, a team, or a theoretical approach. Each concept designed by this term (process, team, or theory) has synonymous designations: upravljanje, rukovođenje, vođenje, uprava, rukovodstvo, to name a few. Then again, management experts would generally fail to agree that menadžment and rukovođenje have exactly the same meaning, but would rather say that rukovođenje is a hyponym of menadžment. On the other hand, they may also claim that the English control is not the equivalent for Serbian kontrola but rather for upravljanje (e.g., quality control is the equivalent for upravljanje kvalitetom), whereas Serbian kontrola is English inspection.

c) Limitations of corpus-based extraction of terms: A term extraction corpus, however adequate and representative of the subject field, can rarely provide all the terminological information necessary for filling in terminological records for a termbase. As a result, some of the data categories may be left empty in a terminological entry. This undoubtedly emphasizes the role of subject-field specialists who are indispensable in completing terminological information for a management TDB. 
Conclusion and Further Research

The main objective of this paper is to draw attention to the benefits that a terminology database for the subject field of management would have for all its potential end-users: management specialists and students encountering terminological inconsistencies and other issues, professional translators, Serbian terminology and language planners, and the general public at large. Despite the obvious complexity of this terminological activity and many obstacles and issues that may be encountered on the way, a Serbian management TDB with equivalents in English would consolidate the existing terminology data in the management field, point to terminology gaps, term variants, preferred terms (based on term frequency), standardized terms (based on their use in terminology standards), term position in the conceptual structure of management, etc. The creation of a terminology database would potentially be a starting point to terminology planners, since it would document the current state of scientific and technical terminology for the subject field in question and thus identify problematic areas that are in need for systematic intervention.

\section{REFERENCES}

[1] Anđelković, J. (2013). Main Issues of Terminology Management in Organizational Sciences. The First International Conference "Teaching English for Specific Purposes", University of Niš, ISBN 978-86-6 I 25-0804.

[2] Antia, E., B. (2000). Terminology and language planning - An alternative framework of practice and discourse, John Benjamins publishing company, Amsterdam/Philadelphia

[3] Bautista-Zambrana, M. R. (2015). Methodologies to Build Ontologies for Terminological Purposes 32nd International Conference of the Spanish Association of Applied Linguistics (AESLA): Language Industries and Social Change, Procedia - Social and Behavioral Sciences, $264-269$.

[4] Blagojević, B. (2011). Developing of the Geologic Terminology for the Geologic Database of Serbia. $17^{\text {th }}$ Meeting of the Association of European Geological Societes, Belgrade, pp.53 -56).

[5] Brač, I., Lončar, M. (2012). Terminology Planning for the Croatian National Terminology Database STRUNA, in Proceedings of the 10th Terminology and Knowledge Engineering Conference (TKE 2012), Aguado de la Cea et al., Eds. Madrid, 19-22 June 2012, pp. 258 - 269.

[6] Cabre, M. T. (1998). Terminology. Theory, Methods and Applications. Amsterdam/ Philadelphia: John Benjamins Publishing Co.

[7] Filipović, J., (2002) Uloga menadžmenta terminologije u kreiranju jezičke politike i procesu jezičkog planiranja: Kako prihvatiti priključak sa svetom?, Primenjena lingvistika br. 3, 73-79, Beograd.

[8] Guidelines for terminology policies (2005). UNESCO: Paris

[9] Jakić, G. (2014). erminologija u organizacionim naukama, Fakultet organizacionih nauka, Beograd, ISBN: 978-86-7680-292-0

[10] Meyer, I., Skuce, D., Bowker, L., and Eck, K. (1992). Towards a New Generation of Terminological Resources: An Experiment in Building a Terminological Knowledge Base. In Proceedings of the 14th International Conference on Computational Linguistics (CO-LING'92) (pp.956- 960). Nantes, France.

[11] Pearson, J. (1998). Terms in Context. Amsterdam / Philadelphia: John Benjamins.

[12] Piper, P. (1998). O velikim i malim jezicima u svetlu lingvističke ekologije. Filološki pregled, 25(1), 67-86.

[13] Stanković, R. (March 2016). Ekstrakcija termina u srpskom jeziku. Paper presented at the Society for Language Resources and Technologies, Faculty of Mining and Geology, University of Belgrade.

[14] Wright, S. E., Budin, G. (1997). Handbook of Terminology Management -Volume 1: Basic Aspects of Terminology Management. Philadelphia, USA: John Benjamins Publishing Company.

Receieved: May 2016.

Accepted: June 2016. 


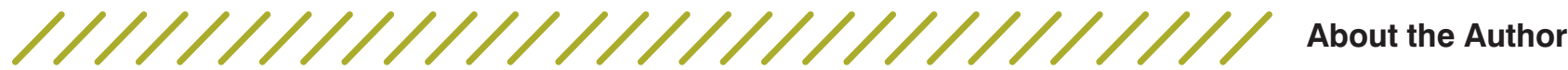

\section{Gordana Jakić \\ University of Belgrade, Faculty of Organizational Sciences gordanam@fon.bg.ac.rs}

Gordana Jakić, Assistant Professor at the Faculty of Organizational Sciences, University of Belgrade. Her current research is based on meaningful and detailed creation and editing of the current state of terminology and its management including synchronic and diachronic language research, terminology harmonization and standardization.

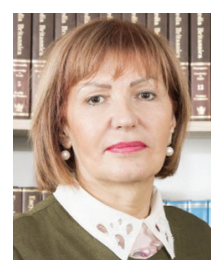

\section{University of Belgrade, Faculty of Organizational Sciences \\ Jelena Anđelković plecasj@fon.bg.ac.rs}

Jelena Anđelković, Teaching Assistant at the Faculty of Organizational Sciences, University of Belgrade, and PhD student at the Faculty of Philology, University of Belgrade. Her fields of interest include: language policy and planning, terminology management, the English language for special purposes, sociolinguistics.

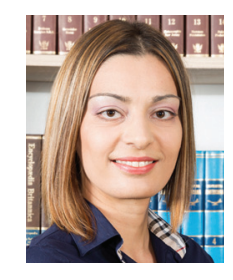

